“İ̧,,Güç” Endüstri İlişkileri ve Insan Kaynakları Dergisi

Cilt:10 Sayı:1 , Ocak 2008, ISSN: 1303-2860

“İs, Güç" The Journal of Industrial Relations and Human Resources

Vol:10 No:1 January 2008, ISSN: 1303-2860

\title{
ÖRGÜTSEL KÜÇÜLME VE ÖRGÜTLERI BEKLEYEN TEHDIT: GERIDE KALAN SENDROMU
}

\section{HALIL YILDIRIM}

Yard.Doç.Dr.Zonguldak Kara Elmas Üniversitesi, İiBF, İşletme Bölümü

\section{ÖZNUR YAVAN}

Araş.Gör.Zonguldak Kara Elmas Üniversitesi, İiBF, İşletme Bölümü

\begin{abstract}
Nowadays, the application of contemporary management approaches by organizations become a common attitude to adopt companies for changing conditions, acquire competitive advantage and sustain competitive power they have. In this respect, organizational downsizing application as a restructuring process take attention as a contemporary managament approach. Downsizing application leads to procure major advantages for the companies whereas can be main causes of some problems. "Survivors syndrome (SS)" is the most important one of these complications. Unless SS which would occur unsuccessfull management of organizational downsizing as a restructuring process, is solved, all expected results from restructuring will not be achieved. Moreover, organization may become less productive and fragile than before, and also could loose competitive power. This study put forward concept, causes and effects of SS and provides suggestions to manage SS which may appear as a concequences of widespread organizational downsizing as a restructuring application after privatization, widely seen recent years in Turkey too.
\end{abstract}

Key Words: Change, Downsizing, Survivor Syndrome, Employee's Motivation 


\section{ÖZET}

Günün değişen şartlarına uymak, rekabet gücü elde etmek veya varolan rekabet gücünü koruyabilmek için örgütler çağdaş yönetim yaklaşımlarını yaygın olarak uygulamaktadırlar. Bu bağlamda yeniden yapılanma kapsamında örgütsel küçülme yaygın uygulama alanı bulan yönetim yaklaşımı olarak dikkat çekmektedir. Işsletmelere büyük avantajlar sağlayan küçülme, aynı zamanda bazı problemlerin de kaynağını oluşturmaktadır. "Geride Kalan Sendromu (GKS)" bu sorunların başında gelmektedir. Örgütsel küçülme şeklinde yürütülen yeniden yapılanmanın iyi yönetilememesinin sonuçlarından biri olarak ortaya çıkabilecek olan GKS'nin çözülememesi durumunda, uygulamadan beklenen sonuçlara ulaşmak mümkün olamayacaktır., Örgüt ilk halinden daha verimsiz, daha kırılgan bir hale gelip rekabet gücünü yitirebilecektir. Bu çalışma son yıllarda, özellikle özelleştirme sonrası Türkiye'de de, örgütlerde sık sık yaşanan küçülme şeklindeki yeniden yapılanma sürecinde karşılaşılabilecek olan GKS'nin kavramsal çerçevesini, nedenlerini, etkilerini ve çözüm önerilerini sunmaktır.

Anahtar Kelimeler: Değişim, Küçülme, Geride Kalan Sendromu, Çalışan Motivasyonu.

\section{Giriş}

Yerel ve global ekonomik eğilimler, özellikle son on yıldır birçok modern örgütü şiddetli bir biçimde ve derinden etkilemektedir. Örgütler, gelecekteki başarıları için bu etkilerin olumsuzluklarını azaltacak ve ortaya çıkan fırsatlardan en yüksek oranda faydalanmayı sağlayacak stratejiler geliştirme ve uygulama çabası içerisindedir. Günümüzün hızlı değişim ortamı büyük örgütleri yavaş ve verimsiz hale dönüştürebilmektedir. Örgütler hızdan denetime, liderlikten yönetmeye, kazanmaktan kazandıklarını korumaya ve müşteriye hizmet etmekten bürokrasiye hizmet etmeye geçmektedir (Slater, 2000:117). Bu noktada örgütlerin hızlı, verimli ve esnek olabilmesini sağlayan küçülme stratejileri, yeniden yapılanma kapsamında uygulama alanı bulan alternatif bir yönetim anlayışı olmaktadır (Kim, 2003:460). Küçülme, değer eklemeyen iş süreçlerine son vererek ve çalışanların sayısını azaltarak bir örgütü daha yetenekli ve verimli hale getirmeyi amaçlayan bir süreçtir. Bu nedenle küçülme şeklindeki yeniden yapılanma, genellikle personel sayısının azaltılmasını, yönetim seviyelerinin elenmesini ve işgücünün yeniden tanımlanmasını gerektirmektedir. Günümüz iş dünyasında, artık örgütlerde hiç kimse ve hiçbir pozisyon için iş garantisi söz konusu değildir.

Genel olarak örgütlerde küçülme trendi 1970'lerin sonlarında başlamıştır. Özellikle Amerikan şirketleri için küçülme bir yaşam şekli 
halini almıştır. Çünkü küçülme girişimlerinin ilki, genellikle daha uzun süren ve sürekli hale gelen küçülmelerle devam etmektedir (Mishra ve diğ., 1998:83). Sears, General Dynamics, General Motors, Citicorp, Digital Equipment, Unisy, United Technologies ve Aetna Life \& Casualty gibi geniş örgütler küçülme uygulamalarının liderleridirler.

Günümüzde küçülme yaklaşımı örgütlerin yeni koşullara ve yaratıcı rekabete ulaşabilmesi için zorunluluk olarak görülmektedir. Kabul edilmiş birçok yararına karşın, küçülme uygulamaları öngörülemeyen bazı büyük problemleri de beraberinde getirmektedir. Örgütlerin istenen başarıya ulaşması ancak kaliteli işgücüyle mümkün olabilmektedir (Wolfe, 31.03.06). Geride kalan çalışanların kalitesi ise yeni örgüt ve yönetime olan tutum, davranış, motivasyon, sadakat ve bağlıı̆ı̆ına dayanarak tanımlanıp ölçülmektedir (Ryan, 1989:40). Bir kurumdaki personelin, iş güvencesinin bulunup bulunmamasına bağlı olarak tutumu, davranışı, performansı ve enerjisi büyük oranda farklılık göstermektedir (Stock, 2001:11). Rekabetçi ve güçlü kalabilmek için sık sık başvurulan bir iş pratiği haline gelen küçülme süreci sonrasında işgücü, Geride Kalan Sendromu (Survivor Syndrom) olarak adlandırılan ve işini koruyabilen işgücünde görülen duygusal yapı ile davranışlardaki karmaşa ve sapma olarak ifade edilen rahatsızlıktan dolayı büyük sıkıntılar yaşayabilmektedir (Fong ve Kleiner, 2004:9).

Sendrom ayn zamanda motivasyonel bir paradoks da ortaya çıkarmaktadır. Daha etkin ve verimli çalışılmazsa örgütler küçülmekte, örgüt küçüldükçe sendromun etkisi artmakta, motivasyon düşmekte dolayısıyla da etkinlik ve verimlilik azalmaktadır (Sahdev ve Vinnicombe, 1998:3). Bu paradokstan kurtulmak ve örgütsel küçülmenin beklenen hedeflerine ulaşmak için ilk yapılması gereken, süreç tamamlandığında ortaya çıkan işten çıkarma sonucu geride kalanların tepkilerine etki eden faktörlerin tanımlanmasıdır. Daha sonra yöneticilerin işten çıkarma sürecini, elde edilen bu veriler ışığında doğru kararlar alarak yönetmesi gerekmektedir. Tepkileri belirleyen faktörlerin birçoğunu yöneticiler etkileyebilmekte ve yönetebilmektedir. Bu sürecin en önemli unsurları hiç kuşkusuz, örgüt ile çalışanlar arasında olumlu etkileşim oluşturacak olan doğruluk/tutarlılıkla birlikte etkili ve kapsamlı iletişimdir. Bunlar, istikrarlı bir küçülme sağlamak ve örgütü ayakta tutmak için zorunlu çalışma alanlarıdır (Donia, 2000:43). Başlı başına iletişim, istenen örgüt kültürünün geliştirilmesinde, adalet ve güvenin sağlanmasında, liderlik faaliyetlerinde ve küçülme sürecine çalışanların katııımının sağlanmasında en etkili araçtır.

Yabancı yazında GKS ile ilgili gerek kuramsal, gerekse ampirik birçok çalışma bulunmaktadır. Yerli yazında ise doğrudan GKS ile ilgili 
çalışmalara rastlanmamakla birlikte, GKS kapsamında yer alan örgütsel bağlılık, iş stresi, örgütsel adalet ve güven üzerine hem kuramsal hem de ampirik çalışmalar bulunmaktadır. Bumin ve Şengül (2000) örgütlerin önemli varlığı olan insanın potansiyelini etkin ve verimli kullanmak için kişi ve çevre unsurları arasındaki ilişkiyi inceleyerek, çalışanları strese iten faktörleri belirlemeye çalışmışlardır. Özellikle kişi ve rol çatışması arasındaki ilişkiyi ampirik çalışma ile ortaya koymuşlardır. Rol sorunlarına bağlı olarak gelişen stresin örgütlerin sağlıklı faaliyetlerini sürdürmesini engelleyeceğini belirterek, ilk işe alımdan, iş yaşamı boyunca çalışanların sürekli olarak takip edilmesi, eğitimlerle desteklenmesi gerektiği sonucuna ulaşmışlardır. Yapılan çalışmanın ulaştığı en önemli sonuç ancak değer verilen insanların değer yaratacağıdır.

Oktay ve Gül (2003) çalışmalarında karizmatik lider özellikleri ile duygusal bağlıık arasındaki ilişkiyi incelemişlerdir. Çalışma, karizmatik liderlerin vizyon belirleme, çevresel duyarlılık gösterme, sıradışı davranışlar sergileme ve mevcut durumu sürdürmemeye yönelik davranışlarının takipçilerin duygusal bağlılıkları üzerinde pozitif etkiler meydana getirdiğini göstermektedir. Esatoğlu vd. (2004) çalışanların içinde bulunduğu örgütü benimsemesi ve örgüt hedefleriyle bütünleşip o doğrultuda çalışmasında örgütsel bağlıığın etkili olduğunu belirterek, örgütsel bağlıı̆̆ı etkileyen faktörleri belirlemeye çalışmıştır. Sağlık sektöründe yaptıkları ampirik çalışmada, kilit pozisyondaki çalışanların bağlılık düzeylerinin orta seviyede olduğu tespit edilmiştir. Yaş, kıdem, kararlara katılım seviyesi, yöneticiler ile iletişim düzeyinin örgütsel bağlılığı etkilediğini belirlemişlerdir.

Çöl (2004), son yıllarda küreselleşme, rekabet gibi şartların getirdiği örgütlerde sahip olunan kaynakların, özellikle insan kaynaklarının en etkin kullanımını ve bu bağlamda çalışanın bağıılığı kavramını inceleme konusu yapmıştır. Örgütsel bağlılık kavramına açıklık getirmeye katkı sağlamak amacıyla mesleki bağlılık, iş arkadaşlarına bağlılık, sadakat ve itaat gibi kavramlarla örgütsel bağlılık arasında ortaya çıkan kavram kargaşası üzerine kuramsal çalışma yaparak yaşanan bu kavram kargaşasına bir ölçüde çözüm getirmeye çalışmıştır.

Çakar (2005) vakıf ve devlet üniversitelerinde örgüte güven, örgütsel adalet ve örgütsel etik gibi faktörleri ele alarak örgütsel bağlılık üzerindeki etkilerini ampirik bir çalışma ile incelemiştir. Konuya devlet üniversiteleri açısından bakıldığında örgütsel güvenin hem prosedürel ve dağıtımsal adalet algısı ile hem de örgütsel etik ile ilişkili olduğu ortaya konulmuş, örgütsel bağlılık açısından ise yalnızca prosedürel 
adalet algısının ve örgütsel etiğin etkili olduğu saptanmıştır. Örgütsel güvenin bağlıık üzerindeki etkileri açısından bulgular örgütsel adalet etkilerinin ortadan kalktığı yalnızca örgütsel etik ve güvenin anlamlı olduğu yönündedir. Vakıf üniversitelerinde ise örgütsel güvenin ve örgütsel bağlıığın yalnızca prosedürel adalet algısı ve örgütsel etik ile ilişkili olduğu görülmüştür. Örgütsel güvenin bağlılık üzerindeki etkileri incelendiğinde prosedürel adalet ve örgütsel güvenin etkili olduğu saptanmışırı. Sonuç olarak çalışmada devlet üniversitelerinde güven oluşumunda dağıtımsal adalete verilen önemin vakıf üniversitelerinde söz konusu olmadığı, kuruma bağlılığın devlet üniversitelerinde örgütsel etik, vakıf üniversitelerinde ise prosedürel adalet ile yakından ilişkilendirilebileceği ortaya konulmuştur.

İslamoğlu ve diğ. (2007) yaptıkları çalışmada kurum içi güveni araştırmış bu bağlamda kuruma güven, yöneticiye güven ve çalışma arkadaşlarına güvene yol açan özellikleri ortaya koymaya çalışmıştır. Demografik farklılık gözetmeksizin çalışmaya katılanların büyük kısmının kuruma güveni oluşturan on faktörden ilk beşinin dürüstlük ve adaletle ilgili faktörler olduğu tespit edilmiştir. Yöneticiye güven konusunda ise ilk üçe giren faktörler yetkinlik ve açık olma ile ilgilidir. Yine kurum içi güven alanlarından çalışma arkadaşlarına güven için ise hoşgörü, sorumluluk sahibi olma, apolitiklik, dürüst ve açık olma ilk sıralarda yer almaktadır. Özellikle çalışanlar arası rekabetin bilgi saklama yoluyla üstlerinin gözüne girme ve politik davranarak yöneticileri etkileme yoluyla kendilerini kurum küçülmelerinde garantiye alma çabalarından dolayı önemlidir.

Şimşek ve Aslan (2007) çalışmalarında mesleki bağlılığın unsurlarıyla örgütsel bağlıı̆̆ın unsurları arasındaki ilişkileri ve her iki bağlılık türünün demografik değişkenler açısından farklı olup olmadığını belirlemeye çalışmışlardır. Temel iş özelliklerinin, iş doyumunun ve rol stresinin örgütsel ve mesleki bağlılık üzerindeki etkileri ayrıca, örgütsel ve mesleki bağlııkların; örgütsel sonuçlar, mesleki faaliyete katılım ve yaşam doyumu üzerindeki etkileri araştırılmıştır. Ampirik çalışma sonuçlarına göre mesleki bağlılıklarla örgütsel bağlılıklar arasında pozitif ve yüksek derecede ilişkiler olduğu bulunmuştur. Ayrıca mesleğe duygusal bağlıı̆ğı örgütten ayrılma niyetini etkilememesi, mesleki faaliyete katıımın bağlıık türleriyle anlamlı ilişki göstermediği, rol belirsizliğinin mesleğe ve örgüte devamlılık bağlıı̆̆ını arttırdığı, iş tanımlarının yapılmasının kayıtsız kalmayı artırdığı ve işteki özerklik artışının sadakati azalttığı sonuçlarına ulaşıımıştır.

Yozgat ve Şişman (2007) yeniden yapılanma yaşamış bir kamu kuruluşunda yapılan değişimin, çalışanların yaş, cinsiyet, eğitim 
durumu, kıdem ve statü gibi demografik özelliklerine göre algıladıkları değişim, iş tatmini ve örgüte bağlılıkları üzerindeki etkilerini incelemeyi amaçlamışlardır. Yapılan ampirik çalışmada kamu kuruluşlarında çalışan bireylerin iş tatmini ve örgüte bağlılıkları ile yapılan değişim arasında düşük bir ilişki bulunduğu belirlenmiştir. Akdoğan ve Cingöz (2007) çalışmalarında Kayseri'de faaliyet gösteren ve küçüldüğü tespit edilen örgütlerde çalışanların örgütsel küçülmeyi nasıl algıladıklarını ortaya koymayı ve bu algılamaların örgütsel bağlılık üzerindeki etkilerini belirlemeyi amaçlamışlardır. Analizler sonucunda kalanların örgütsel küçülme ve işten çıkarmalara yönelik algılama düzeyleri olumlu olmakla birlikte nötre yakın olarak bulunmuştur. Çalışanların duygusal, devam ve normatif bağlılığının ise genel kanının aksine olumlu çıktığı, normatif bağlılığın devam ve duygusal bağlılığa oranla daha yüksek olduğu görülmüştür. İyi planlanmış bir küçülmenin örgütsel bağlılığı azaltmayacağı saptanmıştır. Güney (2007), örgütsel bağlılığın kavramsal çerçevesini ortaya koyarak, örgütsel bağlılık yaklaşımlarını, bağlılık çeşitleri ve örgütsel bağlılık arasındaki farkları, örgütsel bağlılığı etkileyen faktörleri belirlemiş ve örgütsel bağlıığın sonuçlarını ortaya koymaya çalışmıştır.

$\mathrm{Bu}$ çalışmada literatürdeki diğer çalışmalarla benzer olarak, örgütlerin yeniden yapılanma kapsamında küçülmeye gittiğinde örgütlerde çalışmaya devam eden bireylerin içinde bulunabileceği sosyal ve psikolojik durum nedeniyle örgüte bağlılık, iş tatmini ve stres düzeylerinden ve bunun örgüt verimliliğine olabilecek olumsuz etkilerinden söz edilmektedir. Çalışmada farklı olarak küçülen örgütte çalışmaya devam eden bireylerin içinde bulundukları durumun daha geniş kapsamlı bir kavramla açıklanması gerektiği ve bunun tüm yukarıda söz edilen kavramları da kapsayan bir yaklaşımla yabancı literatürlerde çok sayıda kavramsal ve ampirik yansımalar bulan, ancak yerli literatürde bu kapsamda kuramsal ve ampirik olarak incelenmemiş olan Geride Kalan Sendromu kuramsal olarak ortaya konulmaktadır. Bu kapsamda, bu çalışmada, Geride Kalan Sendromu'nun kavramsal çerçevesi, nedenleri, çalışanlar ve örgütler açısından sonuçları ortaya konulmakta ve sendromu yönetim ve çözüm önerileri sunulmaktadır.

\section{Geride Kalan Sendromu'nun Kavramsal Çerçevesi}

GKS, ilk kez 1968'de Niederland tarafından Japonya'ya atılan atom bombasının kişilerde yarattığı etkiyi ifade etmek için kullanılmış bir kavramdır. Bu kavramın yarattığı etkinin benzer şekli örgütlerde yeniden yapılanma girişimleri sonucu geride kalan çalışanlarda da görülmüştür (Türkmen, 20.03.2006; Kim, 2003:462). "Hayatta kalma" terimini örgüt literatüründe ilk defa Joel Brockner (1992) kullanmıştır. Küçülme 
sonrası çalışanlarda motivasyon ve iş tatmini düşüklüğü, moral bozukluğu, kuruma bağlılıklarında ve inançlarında düşüş, bireysel ve iş stresinde, gelecek kaygısı ve endişelerinde artış şeklinde ortaya çıkan reaksiyonlar GKS olarak adlandırılmaktadır. Bir başka deyişle, GKS, küçülme sonrası aynı örgütte çalışmaya devam edenlerin duygusal yapıları ile davranışlarındaki karmaşa ve sapmalar olarak da ifade edilmektedir (Fong ve Kleiner, 2004:9; Kim, 2003:450; Doherty ve Horsted, 1995:26).

Değişen çevreye uyum sağlama amacıyla uygulanan yeniden yapılanma, küçülme ve doğru büyüklük (rightsizing) gibi yaklaşımlar, GKS araştırmacıları tarafından işten çıkarımların yumuşatılmış tabirleri olarak da görülmektedir (Ciancio, 2000:43). GKS, istek dışı yapılan işgücü azaltılmasını takip eden süreçte örgütte kalan çalışanlarda oluşan bir dizi tutum, davranış, duygu ve anlayışı tanımlayan genel bir terimdir (Sahdev ve Vinnicombe, 1998:3). Sendrom, yeniden yapılanma girişiminde küçülmeye gitmiş örgütlerde yaşanan moral bozukluğu, iş güvencesizliği, stres, düşük çalışma performansı ve fizyolojik hastalık gibi sonuç değişkenlerden birini teşkil edebilmektedir (NIOSH, 2000:119; Blondell, 1997:21). Terim, genellikle işten çıkarmalar sonucu geride kalan çalışanların kızgınlık, depresyon, korku, güvensizlik ve yaralanmışık gibi rahatsızlıklarını tanımlamak için kullanılmaktadır (Sahdev ve Vinnicombe, 1998:3). Endişe ve korku etkisiyle iş güvencesizliğinin birleşmesi ise sendromun temel kaynağıdır (James ve Li-Ping Tang, 1996:38).

Günümüzde herhangi bir şirketin birçok çalışanını işten çıkardığına dair bir haberle karşılaşmak mümkündür. Durum böyle olunca, iş güvencesizliği günümüzün önemli gerçeklerinden biri haline gelmektedir (Hammer ve Stanton, 1995:91). Ekonomide iş kayıplarından doğan istikrarsızlık sonucu büyük durgunluklar görülebilmekte, bu da işsizliği arttırmaktadır (Coşkun, 2001:24). İnsanlar işsiz ve parasız kalma tehdidiyle karşılaştıkları zaman ise yaşamlarının tehdit edildiği düşüncesine kapılmaktadır. Bu durum sadece bireyin değil, toplumunda sosyal sağlığını ve yaşam kalitesini büyük oranda etkilemektedir (Türkmen, 20.03.2006).

Herşeyin yolunda gittiği düşünülen bir işletmede bile, yıllarını bu örgütte geçirmiş çalışanlar yönetimin baskısına karşı tepkili olabilmektedirler. Dolayısıyla bir işletmede girişilen örgütsel yeniden yapılanma hareketi (küçülme stratejili), geride kalan çalışanlarda işlevsizlik duygularını arttıran bir faktör haline gelebilmektedir. Ancak çalışanlar ve liderleri sendromunun gerçekliğini ve hem çalışanlara hem 
de örgüte olan etkilerini kabul ederlerse bu dönem başarıyla atlatılabilmektedir (Ciancio, 2000:44).

Yeniden yapılanma kapsamında yaşanan örgütsel küçülme sonucu, geride kalanların işlerini korudukları için memnuniyet duyacakları ve bu moralle daha iyi çalışacakları da düşünülebilmektedir. $\mathrm{Bu}$ günümüz yöneticilerinin kapıldığı yanlış düşüncelerden biridir (Hussey, 1998:72). Çünkü küçülme sonucu geride kalan çalışanların motivasyonu bozulmakta, bu da örgüte bağlılı̆ın azalmasına sebep olmaktadır. Moral ve motivasyon konusunda çok önemli ölçüde ve sıklıkta sıkıntılar çekilmekte ve buna bağlı olarak örgüt, hatalara karşı artan oranda hassaslaşmaktadır. Bu da döngüsel olarak moral ve motivasyonu uzun dönemde azaltmakta ve örgütte sık sık güvensizlik ikliminin hakim olmasına yol açmaktadır. Bunun sonucunda iş stresinin artmasıyla çalışanların performansı önemli ölçüde düşmektedir (Lewin ve Johnston, 1996:93-111).

GKS, işçi ve işveren arasında bir bağı temsil eden ve ahlaki bir yön içeren psikolojik sözleşmenin yıkılmasıyla başlamaktadır. Psikolojik sözleşme, resmi sözleşmede yer almayan, fakat işverenin ne sunacağı, bunun karşılığında çalışanın ne vereceğine dair yazılmayan ve konuşulmayan ama hissedilen karşılıklı söz vermedir (Baruch ve Hind, 1999:299; Robinson ve Rousseau, 1994:246). Bu sözleşme çalışan ve işverenin, istihdam ve davranışlarını temel alan bazı varsayımlar içermektedir. Bu varsayımlar güven, iş garantisi, terfi fırsatları, sadakat, doğruluk, itibar, ilgi, değer takdiri vb. devam etmektedir (Robinson ve Rousseau, 1994:246). Bu durumda sözleşme, çalışanlara iş çevrelerinde güvence ve psikolojik kontrol sağlayan bir faktör haline gelmektedir. Böylece çalışanların kendilerini dolayısıyla işlerini geliştirmeleri için yatırım yapmaları sağlanmış olmaktadır. Ancak küçülme, güvensizliği ve kontrol kaybını örgüte getirerek çalışanın işi değil, kendi iş güvencesini düşünmeye başlamasına sebep olmaktadır. Çalışanın güvensizlik ve kızgınlık duygularını bastırmaya çalışması ise bu duyguların şiddetlenmesine yol açmaktadır. Çalışan sırasıyla stresten moralsizliğe, depresyondan mesleki tükenmişliğe ve yabancılaşmaya varan duyguları yaşayabilmektedir. $\mathrm{Bu}$ duygular etkinliği, üretkenliği, verimliliği azaltmakta ve bu azalış bazen yıllarca sürebilmektedir. Sonuç olarak ise verimlilik amacıyla girişilen yeniden yapılanma yaklaşımı, tamamen ters etki yaratarak örgütü eskisinden daha verimsiz ve yeniliksiz bir hale getirebilmektedir (Ciancio, 2000:44; Donia, 2000:19).

Bir örgütte işten çıkarma yaşandıysa, insanlar hiçbir şey olmamış, her şey mükemmelmiş gibi devam edememektedir. Çünkü 
yıllarca beraber, yan yana çalışıkları arkadaşlarına ne olduğunu düşünmeden hayata devam etmek, normal insan davranışı olarak kabul edilememektedir. Eğer yönetim her şey normalmiş gibi faaliyetlerini sürdürmeye devam ederse, çalışanların bakış açısıyla yönetim ve çalışanlar arasındaki uçurum büyüyecektir. Bu durumda yöneticilerin "onlar" yani karşı taraf, çalışanların ise "biz" olduğu duygusu örgütün her köşesine yerleşecektir (Curtin, 1996:7).

\section{Geride Kalan Sendromu'nu Ortaya Çıkaran Sebepler}

Çalışanların örgüte duydukları bağlıık ve bunun gereği olarak işinde üstün başarı göstererek kendini gerçekleştirme duygusu ile küçülme sonucu işten çıkarmaların çalışanın bu amacını gerçekleştirmesi önünde oluşturduğu engelin bireyde yarattığı çelişki, GKS'nin ortaya çıkışının temeli olarak kabul edilmektedir (Fong ve Kleiner, 2004:13). Çünkü geride kalan çalışanlarda bütünleştikleri eski örgütlerini kaybettikleri hissi, yalnız bırakılma duygusu, başarısızlık hissi ve moral bozukluğu oluşmaktadır. Bunlara belirsizlik ve iş yükünün eklenmesiyle, sendromun boyutları ve örgüte olan etkileri artmaktadır (Sahdev ve Vinnicombe, 1998:5-6).

Küçülme sonucu geride kalan çalışanlar faaliyetlerini genellikle yöneticilerin gündemlerine göre yürütmek zorunda kalabilmektedir. Yöneticiler için işgücü sadece yeni iş gereklerine uymak zorunda olan bir üretim faktörü olarak görülebilmekte, bu durum çalışanın motivasyonunun, performansının ve işe olan bağlıı̆ının azalmasına sebep olabilmektedir (Ciancio, 2000:44). Küçülmenin, yöneticiler tarafından gerekli önem verilmeden (duyurulma şekli, zamanı vs.) uygulanmasıyla da sendrom şiddetlenmekte, örgütün yaşamı tehlikeye girmektedir (Curtin, 1996:7).

Sendromun ortaya çıkmasının bir başka sebebi de geride kalan çalışanların sadece meslektaşlarının kaybı için kederlenmesi değil, "kurtulanlar" oldukları için diğerleri tarafından ihanet ve kabahatli olmakla suçlanabilmesidir (Donia, 2000:21-22). Bu noktada geride kalan çalışanın işten çıkarıımış meslektaşıyla olan yakınığı, sendromun etkilerinin şiddetlenmesine, hissettikleri iş güvencesi seviyesinin daha fazla düşmesine ve kızgınlığın daha da artmasına sebep olmaktadır. Yine geride kalanların işten çıkarılan çalışanlara benzer örgütlerde intiyaç olduğunu görmeleri de, küçülmenin gerekliliğini ve geçerliliğini sorgulamalarına yol açmaktadır. Bu da sendromun ortaya çıkmasına ve etkilerinin artmasına temel teşkil edebilmektedir (James ve Li-Ping Tang, 1996:37-38). Sendromun ortaya çıkmasının temel nedenleri şöyle sıralanabilir (Türkmen, 20.03.2006): 
- İşten çıkarılan çalışanlar ile benzer özelliklere sahip olmak,

- Geride kalanların kendilerine olan güven düzeyleri,

- Örgütsel politikalar ve prosedürler,

- Dış çevre,

- Aile ortamı (bakmakla yükümlü olunan bireylerin olması ve sayısı),

- Yeni iş bulma şansı (yaş, cinsiyet, tecrübe, ekonomik koşullar vb. ),

- Çalışanın maddi olanakları (tüm ailenin gelir düzeyi, yaşam standardı vs),

- İş tatmini ve,

- Sosyal konumdur.

Yukarıdaki sayılan unsurların etkisiyle yoğun olarak ortaya çıkabilecek sendromun sebep olacağı tepkilerin şiddetini arttıran unsurlar şunlardır (Hussey, 1998:73):

- İşten çıkarılmaların derecesi ve duyurulma şekli,

- Geride kalanların bakış açısıyla işten çıkarılmaların sebepleri,

- Geride kalanların işten çıkarılanlarla olan samimiyetleri,

- İşten çıkarılanların iş kaybı sonrası durumları; özel ve iş yaşam şartları,

- Geride kalanların kendilerini ne kadar güvende hissettiği ve

- Yeni duruma alışabilmeleri için verilen desteğin boyutudur.

Yeniden yapılanma sonucu geride kalan çalışanların işten çıkarma ve küçülme süreçlerini kabul etmelerinde ve sendromun olası boyutlarında, adaletli işten çıkarma süreci ve liderlik iki önemli faktörü oluşturmaktadır. Ancak burada liderlik, sürecin adaletli bir şekilde gerçekleştirilmesine oranla daha büyük bir etkiye sahiptir. Çünkü bütün olarak çalışma koşullarının kabul edilmesi, usulen gösterilen ilgiden (hak, adalet, doğruluk v.s.) daha etkili olmaktadır (Karabağ ve diğ., 2004:54-57; Kim, 2003:458-460).

\section{Geride Kalan Sendromu'nun Etkileri}

İşletmeler, değişen sosyal çevreden faydalanmak ve bu çevreye göre kendilerini düzeltmek için yeni bir stratejiye gerek duyuyor ise çalışanların ve örgüt yapısının bu değişime adaptasyonunun kolaylaştırılması gerekmektedir. Bunun için de öncelikle yeni uygulamanın etkileri bilinmelidir. GKS'nin etkilerini çalışanlar ve örgüt üzerindeki etkiler olmak üzere iki ana başılkta incelemek mümkündür. 


\subsection{Geride Kalan Sendromu'nun Çalışanlar Üzerine Etkileri}

Örgütsel küçülmeden en fazla etkilenen çalışanlar, küçülmeyi ekonomik değil sosyal ve psikolojik bir olgu olarak değerlendirmektedir. Yapılan çeşitli araştırmalarda elde edilen bulgulara göre, küçülme girişimlerinden sonra geride kalan çalışanların iş koşullarına olan tutum ve davranışlarında değişiklikler olduğu saptanmıştır. İnsanların sosyal iliş̧kilerinin etkilendiği ve çalışanları birbirine bağlayan bağların parçalandığı gözlenmiştir (Kim, 2003:456). Yöneticiler bu etkilerin bilincinde olması gereken kişilerdir. Ancak yine de işten çıkarma uygulamış bir örgütte yöneticiler, geride kalan çalışanlarından minnettar olmaları yanında, tedbirli olmalarını ve arkadaşlarından olanları affetmelerini beklemektedirler. Duygularını bir kenara bırakmalarını ve çok daha fazla çalışmalarını istemektedirler. Aksi halde hiç konuşulmayan "yoksa" kelimesi büyük bir gürültü ve açıklıkla karşılarına dikilmektedir (Ciancio, 2000:43). Böyle bir belirsizlik ve korku ortamında örgütün karar organları ve çalışanları tutuculuk göstermeyi, mevcut stratejiler doğrultusunda davranmayı, statükoyu sürdürmeyi tercih ederek, yapılan işin gereğinin en azından daha fazla bir performans göstermemektedir. Bunun altında yatan neden, geride kalan çalışanların kötü kararlar alıp cezalandırımak korkusuyla önemli riskler üstlenmeyi istememesidir (Ciancio, 2000:44-45; Lewin ve Johnston, 1996:93-111).

GKS davranışları genelleşmiş kalıplara ulaşmıştır. Örneğin pasif-saldırganlık davranışı en yaygın olanıdır (Ciancio, 2000:44). Arkadaşlarının ve meslektaşlarının gitmesiyle daha tedbirli olan ve savunmacı bir davranış tercih eden çalışanlar, hoşnutsuzluklarını olumsuz söylentiler, ters davranışlar, alaycı, küçümseyici, iğneleyici hatta düşmanca sert konuşmalarla gösterebilmektedir (Maslach ve Leiter, 1997:4). Yönetime sinirlenmiş bir çalışan bu kızgınılı̆ını, misilleme korkusundan, aynı seviyede olan çalışma arkadaşlarına ya da düşük kademedeki çalışanlara yöneltebilmektedir. Aynı kademe çalışanları arasında yaşanan bu şiddet kendini hakaret, aşağılama, kırma, incitme gibi davranışlarla göstermektedir. Burada aynı seviyede olan çalışma arkadaşları zararsız hedefler olmalarının yanında çalışan sayısının düşürülmesi durumundaki potansiyel rakipleri oluşturmaları bakımından da ilk hedeftirler (Ciancio, 2000:44).

GKS'nin başlıca etkileri aşağıdaki gibi sıralanabilir (King, 31.03.06; Türkmen, 20.03.2006; Donia, 2000:22-29; James ve Li-Ping Tang, 1996:37): 
- Korku, güvencesizlik, örgüte aşırı bağımlılık, belirsizlik, örgüt içi karşılıklı bağ noksanlığı, planlama ve iletişim bağlantılarından tatmin olamama, stratejik yöntemlerin noksanlığını hissetme, hissizlik, sürekli değişim duygusu hissetme (Bunlar küçülmenin her aşamasında karşılaşılabilecek belirtilerdir.),

- Sinirlilik, hüsran, içerleme, değersiz hissetme (Bu duygular tam olarak ortaya konulamadığı için farklı problemler - devamsızlık artışı vb. - ortaya çıkmaktadır.),

- Mutsuzluk, depresyon, suçluluk duygusu, yüksek stres düzeyi, kısa dönemli faydaya yönelme (Çalışanların kendi gelecekleriyle ilgili proje yapmamalarına sebep olabilmektedir.),

- Güvensizlik, adaletsizlik, sadakat eksikliği, sürekli olarak işten çıkarmaların bitmiş olmasını dilemek, motivasyon kaybı ve haksızlık yapıldığı duygusu, işten çıkarma süreçlerine kızgınlıktır (Bilgi akışına duyulan ihtiyaçtan dolayı oluşabilmektedir.).

İşten çıkarma yoluyla küçülmenin çalışanlarda yarattığı etkilerin sonucu olarak çalışanların tepkilerinde de değişiklikler meydana gelmektedir. GKS'nin kişilerde yarattığı etkilerin sonucu olarak bu çalışanların işe ve örgüte karşı gösterdiği tepkiler genel hatlarıyla şu şekilde sıralanabilir (King, 31.03.06):

- Dar görüşlülük, kapalılık,

- Riskten aşırı uzaklaşma,

- Düşük üretkenlik,

- Bastırılmışlık,

- Artan devamsızlık,

- Düşük moral,

- Örgütte azamet ve gurur kaybı,

- Değişime karşı artan direniş ve

- Sabotaj olaylarıdır.

Küçülmeye olan tepkilerini geride kalanlar iki boyutta ortaya koymaktadır. Şekil-1'de görüldüğü gibi tepkiler yapıcı/yıkıcı ve aktif/pasif olmak üzere iki ayrı boyutta sıralanmaktadır. Yapıcı geride kalan çalışanlar, küçülmeden önemli bir tehdit ya da zarar görmemiştir ve bu yüzden küçülmeyi tamamlamak için üst yönetimle birlikte çalışmayı istemektedir. Buna karşılık yıkıcı bir tutum sergileyen geride kalan çalışanlar daha çok tehdit hissetmekte veya küçülmeden daha fazla zarar görecekleri yargısına kapılmakta ve küçülmeyi gerçekleştirmek 
için birlikte çalışmayı daha az istemektedirler (Mıshra ve Spreitzer, 1998:569).

Aktif geride kalan çalışan tepkileri, geride kalanların küçülme ile başa çıkabileceği inancına dayanır ve bu noktada çalışanlar fazla iddialı tepkiler gösterir. Örneğin birimlerinde yeniden yapılanma sürecinin bir sonraki aşaması için katkıda bulunmak için bir çabaya girişirler veya küçülmeye resmi ve resmi olmayan itirazlar sunabilirler. Buna karşılık pasif geride kalan çalışanlar küçülme ile başa çıkabilmek için kendilerini daha az yetenek sahibi görürler ve küçülmeye tepki vermede çok düşük kişisel inisiyatifleri vardır ve üstlerinden direktif beklemektedirler (Mishra ve Spreitzer, 1998:569-570).

\section{Şekil-1: Geride Kalanların Tepkileri}

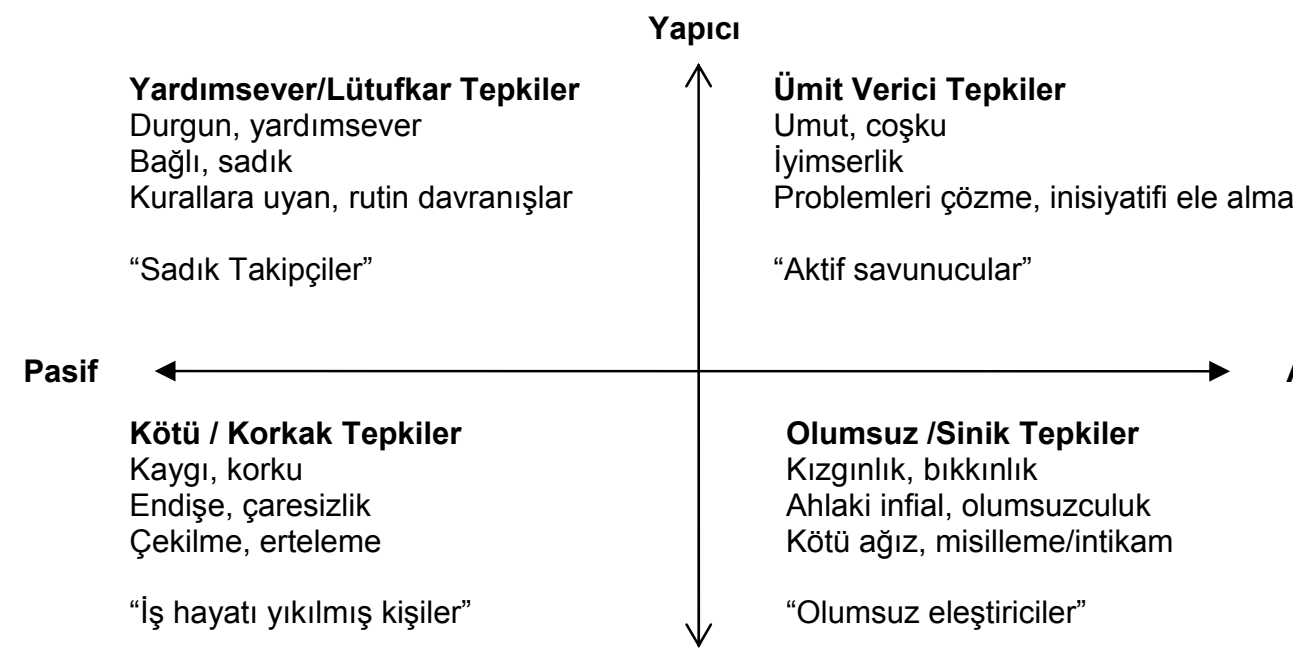

Yıkıcı

Kaynak: Mishra, Aneil K. ve Gretchen M. Spreitzer (1998), Explaining How Survivors Respond to Downsizing: The Roles of Trust, Empowerment, Justice and Work Redesign, Academy of Management Review, Vol. 23, No.3, p.569. 
$\mathrm{Bu}$ iki boyutun birleşimi, geride kalan çalışanların küçülmeye olan tepkilerini korkak, yardımsever, olumsuz/alaycı/sinik ve umutlu olmak üzere dört temel grupta toplamaktadır (Mishra ve Spreitzer, 1998:570).

Örgütsel küçülme çalışanların bağlıığını iki şekilde etkilemektedir. Çalışanların duygusal bağılığı (örgütün değer ve amaçlarının benimsenmesine dayanan bağ|lık) düşük seviyede, devamlıık bağlıı̆̆ı (çalışanların örgüte yaptıkları yatııımları oranında duydukları bağlıık) ise yüksek seviyede olmaktadır. Yine örgüt, işten çıkarma sürecinde işini kaybeden çalışanlara uygun ve adaletli davranırsa geride kalan çalışanlar, duygusal bağılıktaki artışla birlikte pozitif tepki gösteremekte fakat devamlılık bağlıı̆̆ında azalış olmaktadır (Leung ve Chang, 1999:6-8).

Örgütsel küçülmeden önce ve sonraki çalışma koşullarının, küçülme sürecinin kendisinin geride kalan çalışanların zihin sağlığını etkilediği de görülmüştür. İşten çıkarma sonucu geride kalan çalışanların küçülmeden önce ve sonraki davranışlarını inceleyen Kim (2003) çalışmasında, işten çıkarılan çalışanların zihin sağlığının birçok faktör tarafından etkilendiğini ortaya koymuştur ${ }^{1}$. İşten çıkarma sonucu oluşan iş güvencesizliği ile kalp damar rahatsızlığı belirtileri arasında ilişkiler olduğu da saptanmıştır. Sezilen güvensizlik seviyesinin yüksek olduğu durumlarda kalp rahatsızlığı belirtileri sayısının arttığı gözlenmiştir. Laidlaw'ın Amerikan ambulans ünitesi, işten çıkarmaların yoğun olduğu 1999 yılında tavan yapmıştır (Burke, 2001:3-12).

Campbell ve diğerleri (2001) yaptıkları çalışmada, farklı örgüt seviyelerinde bulunan geride kalan çalışanların, en azından işten çıkarma esnasında, iletişim ve danışmanlık konularında farkı tedaviler aldığı bulunmuştur. Çalışmada örgütte güvenin kaybolduğu, çalışanların

${ }^{1}$ Küçülmüş örgütlerde zihinsel sağlığın derecesini ölçmek için Jang'ın psikolojik sağlık dizininden 16 soru Kim (2003) tarafından kavramlaştırımıştır. Bu 16 soru dört alt-boyut içinde kategorize edilmiştir. Bunlar:

Kendine güven: Hayat yaşamaya değer, Belirli işlerde, karar verebilme, Kesinleşmiş işlere hemen başlamak, Problemleri kendi çözebilme.

Endişe / Depresyon: Mutsuz hissetme ve depresyon, Kendine güven eksikliği, Huysuzluk ve sinir, Her yönde kendini diğer insanlardan aşağı görmek, Gerilim altında yaşama.

Hayatiyet / Canlıık: Konforlu ve sağlıklı hissetme, Enerjik hissetme, Temiz ve saf bir zihin.

Uyku rahatsızlığı: Uykuya dalmada zorlanma, Uyanıldığında bir daha uyuyamama, Erken uyanma, Geceleri sinirli ve depresyonda hissetmektir. 
kendilerini kötü hissettiği ve örgütsel moralin azaldığı tespit edilmiştir. Küçülme girişiminin yönetici ve çalışanlarda yarattığı duyguların sıralamalı bir karşılaştırmasını gösteren Tablo-1'de, küçük değişimlerle yönetici ve çalışanların fazla sapmayan bir seyir halinde benzer duyguları yaşadığı görülmektedir. Yönetici ve çalışan küçülme sürecinde son olarak suçluluk duygusu beslemektedir. Çünkü bütün çalışan ve yöneticiler, işten çıkarımanın bir gün kendilerinin başına gelebileceği düşüncesinden kurtulamamakta ve kendilerni suçlu hissetmektedir. Arkadaşlarının işten çıkarılmalarıyla kendilerini büyük bir belirsizlik ve risk içinde bulan geride kalanlar, hüsran ve endişe duygularının yoğunluğuyla "bekle ve gör" tavrı içine girmektedir (Ryan, 1989:40). Bu tavır çalışanların performans ve verimliliklerini olumsuz etkileyebilmekte, çalışan devir hızı artışına da neden olabilmektedir (Wong, 1999:19).

Tablo 1. Yöneticiler ve Yönetici Olmayan Çalışanların Yaşadığı Duyguların Sıralamalı Karşılaştırması

\begin{tabular}{|l|c|c|}
\hline Duygular & $\begin{array}{c}\text { Yöneticilerdeki Duygu } \\
\text { Sıralaması }\end{array}$ & $\begin{array}{c}\text { Yönetici Olmayan } \\
\text { Çalışanlardaki Duygu } \\
\text { Sıralaması }\end{array}$ \\
\hline 1 Stres & 1 & 2 \\
\hline 2 Yorgunluk & 2 & 1 \\
\hline 3 Endişe & 7 & 3 \\
\hline 4 Hayal kırıklığı & 4 & 4 \\
\hline 5 Kaygı & 5 & 5 \\
\hline 6 Kızgınlık & 3 & 6 \\
\hline 7 Üzüntü & 6 & 8 \\
\hline 8 Korku & 8 & 7 \\
\hline 9 Bımışık & 9 & 10 \\
\hline 10 Güven & 11 & 15 \\
\hline 11 Umut & 15 & 9 \\
\hline 12 Memnuniyet & 12 & 13 \\
\hline 13 Mutluluk & 10 & 14 \\
\hline 14 İstek & 13 & 12 \\
\hline 15 Rahatık & 14 & 11 \\
\hline 16 Neşe & 16 & 16 \\
\hline 17 Suçluluk & 17 & 17 \\
\hline
\end{tabular}

Kaynak: Campbell, J. F.; L. Worral ve C. Cooper (2001), Downsizing in Britain and Its Effects on Survivors and Their Organizations, Anxiety, Stres \& Coping, Vol.1, No.1, p.50. 
Küçülmeden sonra, diğer faktörler azalırken meslek otonomisi artış göstermektedir. Bunun sebepleri, küçülmeden sonra geride kalan çalışanların iş yüklerinin artması ve meslektaşlarının sayılarının azalmasıdır. Çünkü işten çıkarma olmadan önceki süreçte aynı görevi daha çok sayıda çalışan yapmakta dolayısıyla bürokrasi artmakta ve bu da yüksek etkileşim oranı meydana getirmekteydi. Bu nedenle çalışanların bağımsız olarak kendi kendine karar verme yetisi ve otokontrol daha azdı. Küçülmeden sonra çalışanların sorumlu oldukları iş kapasitesinin ve meslek otonomisinin artmasına bağlı olarak süreçlerin ve dolayısıyla işlerin hızı artmakta, verimlilik ve performans artışları görülmektedir (Kim, 2003:457; Wong, 1999:28; Maslach ve Leiter, 1997:10-11).

Olumsuz yönlerine rağmen, değişim, yaratma ve yıkım güçlerinin karşılıklı olarak zamana bağlı olmayan etkileşimi olduğu da söylenebilir. Bir örgütte değişim kapasitesinin yaratılabilmesi için üst yönetim tarafından esneklik ve güven gelişimine odaklanılması temel koşullardan biridir. Sherman ve Garland'a(2007:54) göre değişim, yeniden yapılanma ve örgütsel küçülme girişimlerine gösterilen direnç ve sonucu olarak çalışanların yaşadığı olumsuzluklar, beklendiği kadar da fonksiyonsuz bir davranış olmayabilir. Yeniden yapılanma sürecinde yaşanan direnç, yöneticilerle çalışanlar arasındaki duvarları yıkan, açık ve kapalı iletişimin, bağlıı̆ın oluşmasını sağlayan bir unsur haline de gelebilmektedir.

\subsection{Geride Kalan Sendromu'nun Örgüt Üzerine Etkileri}

Örgüte bağlı çalışanlara sahip olmak, örgüt için pozitif sonuçlar doğuran bir durumdur. Çünkü örgüte bağlı çalışanların geçmişleri kadar geleceklerinin de bilinmesi söz konusudur (Fedor ve diğ.., 2006:1-9). İşten çıkarmalardan olumsuz etkilenen çalışanların oluşturduğu bir örgütün başarısının da bu durumdan etkilenmesi kaçınılmazdır. Stres, belirsizlik ve artan iş yükü çalışanın örgüt içi yıkıcı çatışmalarını arttırmakta, takım çalışmalarını azaltmakta, moral ve motivasyonu düşürmekte, kabul edilebilir çalışma seviyesinin kalitesi düşmektedir. Çünkü çalışanlar işleriyle ancak başa çıkabilirken, işten çıkarmalarla işin kapsam ve hacminin artması, belirsizlik ve stresi körüklemektedir (Anonymous, 2002:20; Wong, 1999:28). Stresle ilgili hastalıklar çoğalmakta, mesleki tükenmişlikler yaşanmaya başlamaktadır (James ve Li-Ping Tang, 1996:37). Personel azaltma, şirket stratejisinin ve kültürünün mantıklı bir sonucu olsa bile, uygulamanın uzun dönemde beklenen getiriyi sağlamayabileceği de göz önünde bulundurulmalıdır (Coşkun, 2001:37-38). 
Küçülen bir örgütte üst düzey yöneticiler birçok insandan daha fazla kontrol hissine sahip olmaktadır (Maslach ve Leiter, 1997:43). Ancak yine de küçülen örgütlerdeki diğer bireylerle birlikte üst düzey yöneticiler de, sıranın eninde sonunda kendilerine geleceği düşüncesi ile endişe ve güvensizlik duymaktadırlar. Bu kadar belirsiz ve güvensiz bir ortam çalışanları daha da fazla etkileyerek performanslarının düşmesine, risk alma isteklerinin azalmasına, dolayısıyla örgütün entelektüel sermayesinin sınırlanmasına sebep olmaktadır. Bu durum, küçülme sonrası yeni fikirlerin, üretkenliğin, geliştirmelerin ve yenilikçiliğin olması gereken seviyenin altında kalmasının da sebeplerini oluşturmaktadır (Wright ve Barling, 1998:342).

Örgütsel küçülme sonucu artan iş yükü, örgüt perspektifinden verimlilik anlamına gelse de, birey için harcanan zaman ve enerjiyi ifade etmektedir (Maslach ve Leiter, 1997:38). Bu sebeple iş yükü artışı, geride kalan çalışanların yaşadığı stresin temel nedenini oluşturmaktadır (Greenglass ve Burke, 2000:3). Yapılan araştırmalarda, iş stresi artışının sakatlanma oranını da $\% 100$ ile $\% 900$ arasında artırmış olduğu tespit edilmiştir (Appelbaum ve diğ., 1999:443).

\section{Geride Kalan Sendromu'nun Yönetimi}

Küçülme uygulamış yeni örgütün gelecekteki başarısı, geride kalan çalışanların tepkilerine bağlıdır (Hopkins ve Weathington, 2006:477). İşten çıkarma sonucu geride kalanların tepkilerine etki eden faktörlerin belirlenmesi, yöneticilerin küçülmeyi nasıl yönetecekleri konusunda daha doğru kararlar almasını sağlayacaktır. Tepkileri belirleyen faktörlerin birçoğu kontrol edilebilir ve yöneticiler bunları etkileyip yönetebilmektedir (Coşkun, 2001:29-30; Appelbaum ve diğ., 1999:432).

Eşitlik, güvenlik, iyi yönetim, dürüstlük, yetkilendirme, iyi iletişim, ek haklar ve kişisel destek; çalışanların örgüte olan sadakatlerini etkileyen faktörlerdir (Türkmen, 20.03.2006). GKS'yi ortaya çıkarmamak ya da etkilerini en aza indirmek için işten çıkarma uygulamaları, bütün bu faktörler hesaba katılarak gerçekleştirilmelidir. Bunu sağlamak için de etkin bir işten çıkarma yönetimi uygulanmalıdır.

Daha adil bir küçülme süreci ve daha fazla iş garantisinin sağlanması, sendromun daha az hissedilmesiyle birleşince, akıl ve beden sağ ığı daha iyi olan, nitelikli çalışanlar sağlanabilecektir (NIOSH, 2000:2). Geride kalanların hissedecekleri adalet, küçülmenin niçin meydana geldiği ve nasıl yürütüldüğüne dair olan algılarıyla belirlenmektedir. Geride kalanlar, işten çıkarmanın haklıı̆ııı 
sorgularken aşağıdaki sorulara cevap aramaktadır (Coşkun, 2001:3034):

- İşten çıkarma makul mü?

- İşten çıkarma örgüt kültürü ile uyumlu mu?

- Örgüt önceden kapsamlı bir uyarıda bulundu mu?

- Işten çıkarma uygularken örgüt detayları ne kadar dikkate aldı?

- Yönetim işten çıkarma sebeplerini yeterince açık bir şekilde anlattı mı?

- Maliyet azaltma, üst yönetim tarafından da paylaşıldı mı?

- Kalacak olanların seçilmesine karşılık, işten çıkarılacak çalışanları belirleme de hangi karar kuralları uygulandı?

- Örgüt, işten çıkarma sonrası ortamı yumuşatmaya yardımcı olacak görünür (hissedilir) hizmetler sağladı mı?

- Yönetim, işten çıkarma kararı sürecine çalışanların katılımını sağladı mı?

Dolayısıyla personel azaltımasının haklılığını sorgulayan bu sorular makul, doğru ve doyurucu olarak cevaplanmalıdır. Çünkü, geride kalanların algıladığı adalet, örgüte bağlılıklarını dolayısıyla etkinlik ve meslek tatminlerini etkilemektedir (Karabağ ve diğ., 2004:57; Wong, 1999:27-29). İşgücü sayısını azaltırken dikkat edilmesi gereken beş temel adalet kriteri vardır ve bu kriterlere uyulması büyük önem taşımaktadır. Bunlar (James ve Li-Ping Tang, 1996:39-40):

- Farkıı bakış açılarını dikkate almak,

- Personelin ön yargılarının üstesinden gelmek,

- Sürekli ve tutarlı karar alma kriterlerini kullanmak,

- Kararlar hakkında güncel geri besleme sağlamak ve

- Kararların kökenini doğru açıklamaktır.

Geride kalan çalışanlar, iş süreçlerini geliştirmek için sürekli çalıştıkça, birtakım mesleklerin önemsiz hale geldiğini bilmektedir. Dolayısıyla çalışanlardan sürekli gelişme için çalışmaları istenmeden önce çalışma istikrarı güvence altına alınmalıdır. Yönetim çalışanlara, işleri gelişme sonucu önemsiz hale gelirse işten çıkarılmayacaklarını, önemli bir hata hariç herhangi bir sebepten dolayı işini kaybeden yönetici ve uzman kişiler için "şirket dışında iş bulma" hizmeti verileceğini ya da eğer gerekirse diğer işlere yönelik eğitimin sağlanacağını bildirmelidir (Çetin, 2004:70-71; Mishra ve diğ., 1998:83; Drucker, 1996:74; James ve Li-Ping Tang, 1996:40). 
Küçülme uygulamaları sonucunda birçok örgüt işini yeni kaybetmiş işgücü için yardım programları oluşturmuş ya da oluşturmaktadır. Fakat yine de yaşanan genel ekonomik şartlar sebebiyle geride kalanlar için yapılanlar yetersiz kalmaktadır. Bir daha ki sefere işten çıkarılacak kişinin kim olabileceği düşüncesinin verdiği huzursuzluk, geride kalan çalışanlarda enerjiyi, yaratıcılığı ve üretkenliği düşürmektedir (Dorgan, 2003:98). Bu konuda geride kalan çalışanların yaptıkları işe yönelik becerilerini geliştirmeleri için doğru kararlar almalarını, uygun politikalar belirlemelerini, finansal ve stratejik planlamalar yaparak değişmelerini sağlayacak kariyer yönetim danışmanlığı hizmeti sağlamak, çalışanların kişisel gelişimleri için insan kaynakları bölümü tarafından değerleme danışmanlığı sunmak ve örgütte meydana gelen gelişmelerin anında tüm çalışanlara iletilmesini sağlayacak tüm iletişim araçlarının kullanımı ile etkin iletişim sağlamak gibi faaliyetler geride kalan çalışanlar için faydalı olacaktır (Anonymous, 2002:20). Aynı zamanda geride kalan çalışanlar yönetim tarafından yeni örgüt yapısında nasıl konumlandırılacakları ve uyum sağlayacakları konusunda da bilgilendirilmelidir. Bunun yanında geride kalanlara gelecekteki muhtemel işten çıkarmalar hakkında da doğru bilgiler verilmelidir. Bu noktalarda yönetim rehberliği ve desteği esastır. İş danışma servislerine sözüne güvenilen, samimi ve güven veren konuşmacılar yerleştirilmeli, bilginin sürekliliği ve erişilebilirliği sağlanmalıdır (Appelbaum ve Donia, 2001:132-133). Böylelikle, geride kalan çalışanlarda güven duygusunun oluşması sağlanacak ve dirençten kaynaklanan verimsizliğin büyük oranda üstesinden gelinebilecektir.

Putzier (2002:20) ve Ryan, (1989:42) göre örgütte herhangi bir yüksek harcama ve örgüt fonksiyonlarında aksama yaratmaksızın, yeniden yapılanma sonucu geride kalan çalışanların endişeleriyle yüzleşmek, sorunlarını halletmek ve örgüte geri kazandırmak için yapılabilecekler şunlardır:

- Açıkhava Toplantıları: Çalışanların kendi bölüm ve sahaları dışında kalan toplantılara katılmalarına izin verilmelidir. Böylece resmin daha büyük bir parçasını görmeleri sağlanacak, güven oluşturulabilecek yeni alanlar öğrenilecek ve örgüt içinde yayılan söylentiler etkisizleşecektir.

- $\quad$ Aile Günleri: Çalışanların ailelerini, düzenlenen aile günlerinde işyerlerine davet etmelerine izin verilmelidir. Böylece aileler örgütün halihazır ve ilerlemeyi sembolize eden olaylarına dahil edilerek, bir gelecek olduğu ve onların da bunun bir parçası olduğu hissettirilir. 
- Neşelendirici Aktiviteler: Bu çalışma, "Aile Günü" ile birleştirilebilir. Konuk konuşmacı getirilerek, bir yemek organize edilebilir. Konu, personelin ilgisini çekecek ve neşelendirecek iş dışında bir şeyler olabilir. Geride kalan çalışanların tekrar gülmesini sağlamak tedavi edici ve yerinde bir işlev olacaktır.

- Ortak Düşünce ve Paylaşım Alanı Oluşturma: Bu fikir, iş hakkında bazı sorunları açığa kavuşturmanın yollarını bulmak ve tavsiyeler vermek için çalışanlardan bir komiteyi bir araya getirmektir.

- Katılım: Yöneticilerin işin zorluklarına daha yakın olmasını içermektedir. Bu durum, endişeleri ve değişime olan direnci azaltacaktır.

- Reorganizasyon Takımları: Oluşturulacak takımlar, sorumlulukların yeniden oluşturulmasını, departman amaçlarının birlikte oluşturulmasını, kontrol hizmetleri ve denge sistemlerini, geri besleme değerlemeleri ve yöntem düzeltilmesini sağlayacak katılım araçları olacaklardır.

- Kariyer Yolu: Sağlıklı bir değişim için yönetim öncelikle insan kaynakları ile yakın ilişki içinde olmalı, onlarla çalışma yapmalıdır. Çalışanlar için kariyer yolları, fırsatlar, terfi programları açıkça tanımlanmalı ve yerleştirilmelidir.

- İletişim: (İletişimin bu süreçteki etkisi konusu daha detaylı olarak bu bölümün ileriki kısımlarında anlatılacaktır.).

- Yaratıcı Meydan Okuma: Geride kalan çalışanlar değerli olduklarını hissetmek istemektedir. Bunu hissetmelerini sağlamak için en uygun zaman, bütün geride kalanların örgütü affetme intiyacında oldukları dönemdir. Bu dönemde geride kalanların yaratıcı meydan okumaları için yenilikçi çözümler ve yüksek iş tatmini sağlamak ve genel olarak moral seviyesini yükseltmek en iyi yöntemlerden biri olmaktadır.

İşten çıkarmayı süreç olarak yönetme, dikkatli stratejik planlamalar yapma, yıprandırmadan küçülme, yeniden eğitme, alternatif yerleştirmeler önerme, insanları yeni hizmetler ve roller geliştirmeye odaklama, meslek kriterlerinin geliştirilmesine dahil etme, geride kalanların sendromu artırma yönünde gelişen destekleyici ilişkilerini kırma; sendromun etkilerini azaltabilecek diğer faktörlerdir. Böylece çalışanlar, kendi kaderleri üzerinde kontrolleri olduğu hissine kapılacaklardır. Çalışanlar işten çıkarılırken hiçbir zaman öç alma ve intikam gibi duygular gösterilmemeli ve işe son vermek için "zorunlu işsizlik" bahanesi kullanılmamalıdır. Çünkü bu bütün sürecin başarısını 
etkileyecek ve işini kaybetmiş diğer insanların da kendilerini daha kötü hissetmelerine sebep olacaktır (Baltaş, 2003:30-31; Curtin, 1996:7; Haapaniemi, 1996:28; Ryan, 1989:42).

Sendromun boyutlarının azaltıması için birim yöneticileri, insan kaynakları bölümleri ile birlikte bir şirket politikası ve sorunlarla baş etmede işe yarayacak bir program oluşturmalıdır. Daha önce belirlenmiş aktiviteler, anlaşmalar ve eğitimler mümkün olduğunca iptal edilmemelidir. Böylece çalışanlara "hayat devam ediyor" mesajı verilmelidir (Türkmen, 20.03.2006).

GKS'nin yönetim aracı olarak iletişim, sürecin istikrarlı bir şekilde yönetilmesinde kritik rol oynamaktadır. Küçülme çabalarında öncelikli ve birbiri ile ilgili üç temel kavram; geniş bildirim, doğruluk/tutarlılık ve yüksek iletişim düzeyidir. Bunlar, istikrarlı bir küçülme sağlamak ve örgütü ayakta tutmak için zorunlu çalışma alanlarıdır (Donia, 2000:43). Başlı başına iletişim, örgüt kültürünün geliştirilmesinde, adalet ve güvenin sağlanmasında, liderlik faaliyetlerinde ve küçülme sürecine çalışanların katııımının sağlanmasında en etkili araçtır (Slater, 2000:9).

Küçülme, örgütlerin iş çevresinde kapsamlı değişimler yaratmaktadır (Burke, 2001:6). En basit şekliyle, bir örgütün temel çalışanları işten çıkarıldığında, örgütsel devamlılık kaybedilmektedir. Çünkü işten çıkarmalar sonucu örgüt içi iletişim ve üretkenlik zarar görmekte, örgütteki insanlar ve departmanlar değişmekte, kime, neyin, nasıl söyleneceği bilinememektedir (Wong, 1999:15-16). Illetişimin bozulması ise sendromun en büyük sebeplerinden biri olan örgütsel adaletin azalmasına yol açmaktadır (Burke, 2001:6). Çünkü örgütsel adalet kararın kendisinden çok alınma ve iletilme şeklini içermektedir. Bu bağlamda çalışanın işten çıkarılma kararı olumsuz bile olsa iletişim şekli ve zamanı örgütte adaletli uygulamanın bulunduğu hissini oluşturabilmektedir (Donia, 2000:38).

İşten çıkarma döneminde iletişim seviyesinin yüksek olması halinde yaşanan sendrom düşük düzeyde kalacak, örgüt içi iletişim seviyesinin düşük olması durumda ise sendrom yüksek düzeyde olacaktır (Wong, 1999:27-35). Dolayısıyla, küçülme sürecinde iletişim, geride kalanların ve örgütün yaşayabileceği olumsuz şartlardan kurtulmasını veya olumsuzlukların etkisinin azalmasını sağlamada büyük rol oynamaktadır. Küçülmenin iletilme şekli, çalışanın uygulamaları doğru ve zamanlı olarak kabul edip algılamasını sağlamaktadır. $\mathrm{Bu}$ da, küçülme girişimleri örgütün başarısızlığa sürüklenmesine sebep olabilecek kadar büyük boyuta taşıyan örgüt içi söylentilerin yok edilmesi için önemlidir. İşten çıkarma duyurusu, üst 
yönetim tarafından, söylentiler oluşmadan önce ve hafta başında sabah erken saatlerde yapılmalıdır. Ayrılacak olan çalışanlara sağlanacak avantajların duyuru yapılırken açıklanması da, giden ve kalan çalışanların yönetime olan güvenini sağlamlaştıracak, panik havasının azalmasına sebep olacaktır (Türkmen, 20.03.2006; Donia, 2000:33).

Çalışanlarla kötü haberleri paylaşmak, kesinlikle acısız ve zahmetsiz bir iş olarak düşünülemez. Çalışanın güvensizlik ve kızgınlık duygularını yoğun olarak hissettiği bu dönemde, her iki tarafın da dürüst iletişim kurması, gerekirse danışman yardımı alması faydalı olabilmektedir (Ciancio, 2000:45; Mishra ve diğ., 1998:88). Çünkü küçülme stratejilerinin başarısında iletişim temel faktör olmaktadır (Wolfe, 31.03.2006). Bu bağlamda çalışanlara günlük veya haftalık haber mektupları gönderilebilir. Çalışanlar için 24 saat yardım hattı kurulması da, söylentilerin kontrolü ve örgüte hakim olan son duruma ilk kaynaktan ulaşılabilmesini sağlaması açısından faydalı olacaktır (Curtin, 1996:7).

İletişim şekli, sadece soruların cevaplanması şeklinde olmamalıdır. Tekrarlı, tutarlı ve sık sık iletişim sağlanmalıdır (Donia, 2000:44). Çalışanlar, küçülmenin örgütü niçin gençleştireceğini bilmelidir. Çünkü vizyonun daha büyük bir parçasını gören çalışan kendini daha kontrollü hissedecektir (Mishra ve diğ., 1998:91). İletişim kurulduğu her an, çalışana verilen önem öne çıkarılmalıdır (Türkmen, 20.03.2006).

Meydana gelen değişimler konusunda çalışanların yeterli oranda bilgilendirilmesi konusundaki başarısızlık, değişimi gerçekleştirmeden sorumlu orta kademe yöneticilerin bu görevler için yeterli eğitim almaması, ortak amaçlar ve performans standartlarının açık olmamasından da kaynaklanabilmektedir (Appelbaum ve diğ.., 1997:280-281). Dolayısıyla küçülme şeklinde yürütülen yeniden yapılanma sürecinde aktif görev alan üst ve orta kademe yöneticilerine süreci kavrama ve yönetme konusunda gerekli tüm bilgi donanımı sağlanmalıdır. Yöneticilere karşılaşabilecekleri hiçbir şey sürpriz olmamalıdır.

Örgütler küçülürken iki zorunlu konu üzerine eğilmelidirler. Bunlar küçülme öncesinde, esnasında ve sonrasında adaleti elden bırakmamak, adaletsizlikleri gözlemek ve iş çevresindeki değişimleri değerlendirmek için geride kalan çalışanların küçülme sürecine dikkatli bir şekilde uyum gösterip göstermediklerinin farkına varmaktır. Küçülmenin adaletsiz bir şekilde gerçekleştirilmesi sonucunda geride kalan çalışanların örgüte olan bağlılıkları azalabilmektedir. Ancak çalışanları ile dürüst ve düzenli bir şekilde iletişime geçen örgütler 
yüksek seviyedeki bağlılık düzeylerini koruyabileceklerdir (Mau, 2002:47). Bu noktada önemli diğer konu küçülme uygulamış bir örgütte söylentiler ve doğru olmayan inanışların bir kişiden diğerine etkili ve hızlı bir şekilde dolaşmasıdır. Söylentiler hem bireyleri hem de örgütü yaralayan şeylerdir ve yöneticiler söylenti çarkının nasıl kontrol altına alınıp ortadan kaldırılabileceği konusunu gözden kaçırmamalıdır. İletişim hattı açık tutularak söylenti döngüsü ortadan kaldırılmalıdır (Appelbaum ve diğ.., 1997:283-284).

Sendromun temel sebeplerinden biri olan iş güvencesi konusunda çalışanların düşünceleri de, GKS'nin etkilerinin azaltılmasında büyük faktör olmaktadır. Çalışanın iş güvencesinin düzeyini; algılanan tehdit ve algılanan kontrol belirlemektedir. Algılanan tehdit, çalışanların gelecekte mesleklerini kaybedecekleri konusundaki anlayışlarıdır. Algılanan kontrol ise, iş kayıplarının olumsuz etkilerini azaltma konusunda çalışanların veya örgütün sahip olduklarına inandıkları kontrol derecesini ifade etmektedir (Hopkins ve Weathington, 2006:478). Örgütte iyi yönetilen bir iletişimle çalışanların iş güvencesi konusundaki algıları yönetilerek sendromun etkileri sınırlandırılabilir.

Küçülme yaşamış örgütte çalışmaya devam eden yöneticiler de en az diğer çalışanlar kadar sıkıntı yaşamaktadır. Değişen ve değişim sürecinde "kötü haberi veren ve uygulayan" kişi olarak eskisi kadar dostça olmayan ortamda çalışmak zorunda kalmaktadırlar. Yeni örgüt ortamında da yöneticilerin iş tanımları ve kendilerinden beklenenler değişmemiş ve hatta GKS yaşayan ve yaşama yolunda olan çalışanları tekrar örgüte kazandırma gibi yeni bir misyon da yüklenmişlerdir. Yöneticilerinde bu süreçten başarılı ve daha güçlü çıkabilmesi ve yeni misyonlarını örgüte katkı yapacak şekilde gerçekleştirebilmeleri için onları geliştirici çalışmalar yapılmalıdır.

Daha önce belirtildiği gibi geride kalan çalışanlar tepkilerini iki farklı boyutta ve dört temel şekilde ortaya koymaktadırlar. Çalışanların bu temel gruplardan (bkz. Şekil-1) hangilerine girdiği iyi analiz edilerek "sadık takipçiler ve aktif savunucular"ın değişim sürecine katkıları en yüksek seviyede tutulmalı, "iş hayatı yıkılmışlar"ın endişeleri giderilerek hem kendilerine hem de örgüte olumlu katkı yapmaları sağlanmalı, "olumsuz eleştiriciler"inde kazanılması sağlanmalı veya en azından olumsuz etkileri ortadan kaldırmak için gerekli önlemler alınmalıdır. Bu noktada personel güçlendirme için özel çaba gösterilmelidir.. Çalışanlara yeni örgütün önemli bir parçası oldukları hissi kazandırılmalıdır (Appelbaum ve diğ., 1997:282-284).

Son olarak, küçülmeden sonra çalışanların örgüte olan bağlıı̆̆ını sağlamak için özel çaba gösterilmedikçe bu yönde bir 
gelişme sağlanamamaktadır. Geride kalan çalışanların örgüte olan bağlılığını ortaya çıkarmak ve yerleştirmek için insan kaynakları yönetimi politika ve uygulamalarının örgüt stratejileri ile bütünleştirilmesi gerekmektedir. Örgüte bağlılığın ortaya çıkarılması ve uzun dönemli sürdürülmesi için bütünleştirilmiş insan kaynakları yönetimi uygulanmalıdır (Coffey, 2000:7).

\section{Sonuç}

1970'lerin sonlarında itibaren küçülme örgütlerde genel bir trend haline dönüşmüştür. Örgütlerin hızlı, verimli ve esnek olabilmesini sağlayan küçülme stratejileri, yeniden yapılanma kapsamında alternatif bir yönetim anlayışı olarak uygulama alanı bulmaktadır. Küçülme uygulamaları ile değer eklemeyen iş süreçleri ortadan kaldırılarak ve çalışanların sayısını azaltılarak örgütler daha yetenekli ve verimli hale getirmek amaçlanmaktadır. Sonuç olarak işgücünün sayısında azaltma ile sonuçlanan bu uygulama, iş dünyasında, artık örgütlerde vazgeçilmez pozisyon ve çalışan kalmadığı gerçeğini açıkça belirlemektedir.

Bir örgütün ekonomik ve sosyal olarak iç çevresinde, küresel anlamda dış çevresinde yaşanan hızlı değişimler, örgütlerin en azından mevcut durumlarını koruyabilmeleri için hızlı bir biçimde ve sürekli olarak değişmelerini gerektirmektedir. Yaşanan değişime uyum sağlayabilmek için farklı yönetim yaklaşımlarını uygulama çabasına girişen örgütler, verimli ve etkin olabilmek için bir çözüm anlayışı olarak yeniden yapılanma kapsamında küçülme uygulamasını tercih etmektedir. Ancak örgütlerin yeni koşullara ve yaratıcı rekabete ulaşabilmesi için önemli bir unsur olarak görülen küçülme yaklaşımının birçok yararına karşın, büyük problemleri de beraberinde getirdiği görülmektedir. Örgütlere rekabet gücü sağlamada sahip olduğu maddi unsurların yanı sıra maddi olmayan unsurların da büyük önemi vardır. Maddi olmayan unsurların en önemlilerinden biri olan insanın örgüte katkısı olumlu tutum ve davranışlarına bağlıdır. Küçülme uygulamaları sonrası, işini koruyabilen ve geride kalan olarak adlandırılan çalışanların örgüte rekabet yolunda beklenen katkıyı sağlamalarında bu unsurlar anahtar rol oynamaktadır. Küçülme süreci ve sonrasında çalışanlar ve yönetim GKS'den dolayı büyük sıkıntılar yaşayabilmektedir. Sendrom hem çalışanları hem de örgütü etkilemektedir.

İyi yönetilmeyen sendrom, fasit daireye neden olabilmektedir. Daha etkin ve verimli çalışabilmek için örgütler küçülmekte, örgüt küçüldükçe sendromun etkisi artmakta, etkinlik ve verimlilik 
azalmaktadır. Hem küçülmeden beklenen faydanın elde edilmesi hem de bu fasit daireden kurtulmanın ilk ve en önemli adımı küçülme sürecinin etkin yönetimidir. Sürecin etkin yönetimi, geride kalanların tepkilerine etki eden faktörlerin tanımlanmasıyla başlamaktadır. Etkin yönetim ile tepkileri belirleyen faktörlerin birçoğunu yönlendirilebilmekte ve yönetebilmektedir. Bu sürecin en önemli unsurları hiç kuşkusuz, örgüt ile çalışanlar arasında olumlu etkileşim oluşturacak olan kapsamlı bildirim, doğruluk ve iletişimdir. Özellikle iletişim, istenen örgüt kültürünün geliştirilmesinde, adalet ve güvenin sağlanmasında, liderlik faaliyetlerinde ve küçülme sürecine çalışanların katılımının sağlanmasında en etkili araçtır. İyi yönetilen küçülme şeklindeki yeniden yapılanma süreci örgütlerin bu geçiş dönemlerini sağlıklı atlatmasını sağlayacak, geride kalanların tutum ve davranışlarını olumlu yönde geliştirecek ve rekabet gücünü oluşturan unsurların en önemlisi olan insan unsurunun etkin katılımını sağlayarak, daha güçlü ve barışık bir örgüt kültürü oluşmasına yardımcı olacaktır.

Bu çalışma gerek dünyada gerekse Türkiye'de hız kazanan örgüt küçülmelerinin en önemli sonuçlarından olabilecek çalışanların yaşayabileceği GKS'nun kuramsal çerçevesini ortaya koymaktır. Çalışma, örgütsel bağlılık, tükenmişlik, iş tatmini, adalet algısı, iş stresi gibi çalışanların içinde bulunabileceği sosyal ve psikolojik durumdan bir adım sonrası olan GKS incelemesi açısından bu kavramlardan daha geniş bir çerçevededir. Ancak çalışma, GKS kapsamlı modelini oluşturma açısından eksik bulunmaktadır. Bununla birlikte yerli literatürde kapsamlı GKS modeli oluşturacak çalışmalara temel oluşturacak kavramsal bilgiler sunmaktadır. Daha sonra yapılacak ampirik bir çalışma bu alandaki bilgileri ve GKS'nin anlaşılmasını derinleştirecektir. 
KAYNAKÇA

Akdoğan, Asuman ve Cingöz, Ayşe (2007), "Küçülme Stratejisinin Çalışanların Örgüte Bağlııkları Üzerindeki Etkileri: Kayseri Ili’nde Bir Araştırma”, 15. Ulusal Yönetim ve Organizasyon Kongresi Bildiriler Kitabı, Sakarya Üniversitesi IIBBF İşletme Bölümü, Sakarya, ss. 592-600.

Allen Tammy D., Freeman, Deena M. ve Russel, Joyce E.A. (2001), "Survivor Reactions to Organizational Downsizing: Does Time Ease the Pain", Journal of Occupational and Organizational Psychology, 74, pp.145-164.

Anonymous (2002), "Life After Downsizing," Human Resource Management International Digest, 10, 3, pp.19-21.

Appelbaum, Steven H., Delage, Claude, Labib, Nadia ve Gault, George (1997), "The Survivor Syndrome: Aftermath of Downsizing", Career Development International, 2/6, MCB University Press, Canada, pp. 278-286.

Appelbaum, S.H., Schmidt, S.L., Peytchev, M. ve Shapiro, B. (1999), "Downsizing Measuring The Costs of Failure," Journal of Management Development, Vol.18, No.5, pp.436-463.

Appelbaum, Steven H. ve Donia, Magda (2001), "The Realistic Downsizing Preview: A Multiple Case Study, Part I: The Methodology and Results of Data Collection," Career Development International, 6, 3, pp.128-148.

Baltaş, Zuhal (2003), Değişimde Değer Yaratmak - Kriz ve Yeniden Yapılanma Sürecinde Çalışanın El Kitabı, Ikinci Basım, İstanbul: Remzi Kitabevi.

Baruch, Yehuda ve Hind, Patricia (1999), "Perpetual Motion in Organization: Effective Management and the Impact of the New Psychological Contracts on "Survivor Syndrome'”,' European Journal of Work and Organizational Psychology, 8, 2, pp.295-306.

Blondell, Jackie (1997), "The Truth Abaut Downsizing," Charter, 68, 9, pp.1822.

Brockner, J. (1992), "Managing The Effects of Layoffs on Survivors," California Management Review, Vol.34, No.16, pp.9-28.

Burke, Ronald J. ve Greenglass, Esther R. (2001), "Hospital Restructuring and Psychological Burnout in Nursing Staff," Nursing Management, Volume 20, Number 1/2, pp.61-71.

Bumin, Birol ve Şengül, Arzu (2000), "Insan Kaynaklarının Değerliliği ve Organizasyonlarda Role Dayalı Stres Kaynakları Üzerine Bir Araştırma" 8. Ulusal Yönetim ve Organizasyon Kongresi, Erciyes Üniversitesi, Nevşehir, ss. 571-579.

Campbell, J. F., Worral, L. ve Cooper, C. (2001), "Downsizing in Britain and it's Effects on Survivors and Their Organizations," Anxiety, Stres \& Coping, Vol.1, No.1, pp.35-69.

Ciancio, Jack (2000), “Survivor's Syndrome,” Nursing Management, pp.43-45. 
Coffey, Miachael (2000), "Developing and Maintaining Employee Commitment and Involvement In Lean Construction", http://www.iglc.net/conferences/2000/Papers/ Coffey.pdf, 14.06.2007.

Coşkun, Sevda Yaşar (2001), Stratejik Küçülme (Downsizing) ve Finansal Performans: (IMKB'deki Firmalarda Bir Uygulama), (Yayınlanmamış Yüksek Lisans Tezi), Sakarya Üniversitesi S.B.E., Sakarya, p.24-38.

Curtin, Leah L. (1996), "Surviving "Survivor Syndrome"," Nursing Management, p.7-8.

Çakar, N.Demircan (2005), "Adalet ve Etik Algılarının Kuruma Güven ve Bağlıık Üzerindeki Etkisi: Vakıf ve Devlet Üniversitelerinin Karşılaştırılması", 13. Ulusal Yönetim ve Organizasyon Kongresi, Marmara Üniversitesi lïBF İşletme Bölümü, Ankara, ss. 105-108.

Çetin, Canan (2004), "Toplam Kalite Yönetimi Felsefesinde Kültürel Yapı Taşları," Mercek, MESS, ss.65-78.

Çöl, Güner (2004) "Örgütsel Bağlılık Kavramı ve Benzer Kavramlarla İlişkisi”, "IŞ̧ Güç" Endüstri İlişkileri ve Insan Kaynakları Dergisi, 6, 2, http://www.isgucdergi.org/index.php?arc=arc_view.php

\&ex $=233 \&$ inc $=$ arc \& cilt $=6 \&$ sayi $=2 \&$ year $=2004$

Doherty, Noeleen ve Horsted, Jim (1995), "Helping Survivors to Stay on Board", People Management, January 12, pp.26-31

Donia, Magda (2000), "RDP-A Management Intervention in the Prevention of Survivor Syndrome, A Thesis of The Faculty of Commerce and Administration, Concordia University, pp.1-212.

Dorgan, William J. (2003), "Depression and Survivor's Syndrome," Manager's Workshop, p.98.

Drucker, Peter F. (1996), Gelecek İçin Yönetim, (Çev.:Fikret Üçcan), Dördüncü Baskı, Türkiye İs Bankası Kültür Yayınları, Yayın No: 327, p.74.

Esatoğlu, A.Ezel, Sarp, Nilgün ve Karagöz, Sevgül (2004), "Hastane Işgörenlerinin Örgütsel Bağlılık Düzeylerinin Belirlenmesi”, 12. Ulusal Yönetim ve Organizasyon Kongresi, Uludağ Üniversitesi IïBF Işsletme Bölümü, Bursa, ss. 320-325.

Fedor, Donald B., Caldwell, Steven ve Herold, David M. (2006), "The Effect of Organizational Changes on Employee Commitment: A Multilevel Investigation", Personnel Psychology, 59, 1, pp. 1-29.

Fong, Kim ve Kleiner, Brain H. (2004), "New Development Concerning the Effect of Work Overload on Employees," 27, 4/5, pp.9-16, 15.03.06.

Greenglass, E. R., Burke, R. J. (2000), "Application of an Impact of Restructuring Scale to The Healthcare Sphere ," http://www.cchse.org/Forum/Greenglass\%20Part\%202 \%20.pdf.

Güney, Semra (2007), "Örgütsel Bağlılık”, Yönetim ve Organizasyon (Ed. Salih GÜNEY), Nobel, Ankara. 
Haapaniemi, Peter (1996), "Survivor Syndrome," Chief Executive, p.13, http://proquest.umi.com/pqdweb?index $=24 \&$ did $=9834985 \&$ SrchMode $=1 \&$ sid $=2$ $\& F m t=6 \& V I n s t=P R O D \& V T y p e=P Q D \& R Q T=309 \& V N a m e=P Q D \& T S=11841593$ $65 \&$ clientld $=63522$

Hammer, Michael ve Stanton, Steven A. (1995), Değişim Mühendisliği Devrimi - Ne Yapmalı, Ne Yapmamalı?, (Çev.:Sinem Gül), İstanbul: Sabah Kitapları, p.91.

Hopkins, Sharon M. ve Weathington, Bart L. (2006), "The Relationship Between Justice Perceptions, Trust and Employee Attitude in a Downsized Organization", The Journal of Psychology, 140, 5, pp. 477-498.

Hussey, David (1998), (Daha lyi Nasıl...) Değişim Yönetimi, (Çev.: Ali Çimen), İstanbul: Timaş Yayınları, pp.72-73.

İslamoğlu, Güler, Birsel, Melek ve Börü, Deniz (2007), Kurum İçinde GüvenYöneticiye, İş Arkadaşlarına ve Kuruma Yönelik Güven Ölçümü (Alan Araştırması ve Sonuçları), İnkılap Kitabevi, İzmir.

James, Teri-Ann Winston ve Tang, Thomas Li-Ping (1996), "Downsizing and the Impact on Survivors-A Matter of Justice," Employment Relations Today, 23, 2, pp.33-41.

Kim, Wang-Bae (2003), "Economic Crisis, Downsizing and "Layoff Survivor's Syndrome"', Journal of Contemporary Asia, 33, 4, pp.449-464.

King, Deborah (2002), "Survivor Syndrome," Leaming to Live with Downsizing, http://www.oser.state.wi.us/docview.asp?docid=1794, 31.03.06.

Lewin, Jeffrey E. ve Johnston, Wesley J. (1996), "The Effects Of Organizational Restructring on Industrial Buying Behavior: 1990 and Beyond," Journal Of Business \& Industrial Marketing, Vol.11, No.6, MCB University Press, pp. 93111.

Leung, Alicie S.M ve Chang, Ludwig M.K. (1999), "The Impact of Organizational Downsizing: Psychological Dynamics on Surviving Managers", The First International Conference on Critical Management Studies, Universirty of Manchester, pp. 1-27.

Mau, Dianne Cheryl (2002), "Survivors of Downsizing: Informal Learning of Older Adults Who Remain in the Workplace After Their Organization Experiences a Downsizing", Degree of Doctor of Education Dissertation, Columbia University.

Maslach, Christina ve Leiter, Michael P. (1997), The Truth About Burnout, San Francisco: Jossey-Bass Publishers, pp.4-43.

Mishra, Karen E., Spreitzer, Gretchen M. ve Mishra, Aneil K. (1998), "Preserving Employee Morale During Downsizing," Sloan Management Review, 39, 2, Banking Information Source, pp.83-95.

Mishra, Aneil K. ve Spreitzer, Gretchen M. (1998), "Explaining How Survivors Respond to Downsizing: The Roles of Trust, Empowerment, Justice and Work Redesign", Academy of Management Review, Vol. 23, No.3, pp.567-588. 
Oktay, Ercan ve Gül, Hasan (2003), "Çalışanların Duygusal Bağlııklarının Sağlanmasında Conger ve Kanungo'nun Karizmatik Lider Özelliklerinin Etkileri Üzerine Karaman ve Aksaray Emniyet Müdürlüklerinde Yapılan Bir Araştırma" http://www.sosyalbil.selcuk. edu.tr/sos mak/makaleler\%5C Ercan\%200ktay\%20-\%20Hasan\%20G\%C3\%9CL\%5C403-428.pdf.

Önder, Çetin ve Wasti, S. Arzu (2002), "İ̧ Güvencesi Endeksi ve Iş Güvencesi Memnuniyeti Ölçeği: Güvenilirlik ve Geçerlik Analizi, Yönetim Araştırmaları Dergisi, 2 / 1, Başkent Üniversitesi I.I.B.F., Ankara, ss. 23-46.

Özgen, Hüseyin, Danışman, Ali ve Karabağ, Solmaz Filiz (2004), "Küçülme (Downsizing) Sürecinde Bulunan İşletmelerde Çalışanların Tutum ve Davranışları Üzerine Bir Araştırma", 12. Ulusal Yönetim ve Organizasyon Kongresi, 27-29 Mayıs,Uludağ Üniversitesi I.I..B.F. İşletme Bölümü, Bursa, ss. 54-58.

Pepper, Lewis D. (2000), "The Impact of Downsizing and Reorganization on Employee Health and Well-being at the DOE LANL Facility," National Institute for Occupational Safety and Health (NIOSH), Brief Report of Research Grant Findings, Los Alamos Edition, Final Report, pp.1-135.

Putzier, John (2002), "Moving Past Survivor Syndrome," Executive Excellence, 19, 1, p.20.

Robinson, L. S., Rousseau, D.M. (1994), "Violating The Psychological Contact: Not The Exception But the Norm," Journal of Organizational Behaviour, Vol.15, No.3, pp.245-260.

Ryan, George R (1989), "Dealing With Survivor's Of Reorganization," Research Technology Management, 32, 2, pp.40-42, http://proquest.umi.com/pqdweb?index $=34 \& d i d=$ $769998 \&$ SrchMode $=1 \&$ sid $=2 \& F m t=6 \& V I n s t=P R O D \& V T y p e=P Q D \& R Q T=309 \&$ VName $=P Q D \& T S=1184159639 \&$ client $/ d=63522$.

Sahdev, Kusum ve Vinnicombe, Susan (1998), "Downsizing and Survivor Syndrome: A Study of HR's Perception of Survivor's Responses," Human Resoure Management, Cranfield University, pp.1-30.

Sherman, Scott W. ve Garland, Gail E. (2007), "Where to Bury the Survivors? Exploring Possible Ex Post Effect of Resistance to Change", S.A.M. Advanced Management Journal, 72, 1, pp. 52-62.

Slater, Robert (2000), Jack Welch ve General Electric'in Yolu - Efsanevi CEO'nun Yönetim Anlayışı ve Liderlik Sırları, (Çev: Türkan Arıkan \& Saadet Özkal), Üçüncü Basım, İstanbul: Literatür Yayıncılık.

Stock, Rosamund (2001), "Socio-Economic Security, Justice and the Psychology of Social Relationship," International Labour Office, Geneva, pp.173.

Şimşek, Şerif ve Aslan, Şebnem (2007), "Mesleki ve Örgütsel Bağlıı̆ın, Temel İs Özellikleri, Rol Stresi, Örgüte İlişkin Davranışsal Sonuçlar, İş ve Yaşam Doyumuyla İlişkilerinin Araştırılması", 15. Ulusal Yönetim ve Organizasyon 
Kongresi Bildiriler Kitabı, Sakarya Üniversitesi IïBF Iş̧letme Bölümü, Sakarya, ss. 724-733.

Türkmen, i (2000), "Kriz Ke Küçülme," http://www.koniks.com/topic.asp?TOPIC_ID =770, 20,03,2006, ss.1-13.

Wasti, Arzu S. (2000), "Meyer ve Allen'in Üç Boyutlu Örgütsel Bağlıılk Ölçeğinin Geçerlilik ve Güvenilirlik Analizi”, 8. Ulusal Yönetim ve Organizasyon Kongresi, Erciyes Üniversitesi, 25-27 Mayıs, Nevşehir, pp. 401-411.

Wolfe, Helen (2006), "Survivor Syndrome: Signs, Symptoms, Strategies", http://www. employment-studies.co.uk/news/131art3.php, 31.03.06

Wong, Jennie (1999), "Organizational Commitment and Layoff Survivor Syndrome: The Relationship Between Communication and Downsizing," Human Resource Management, pp.1-74.

Wright, B. ve Barling, J. (1998), “The Executioners' Song': Listening to Downsizers Reflect on Their Experiences, "Canadian Journal of Administrative Sciences, Vol.15, No.4, pp.339-355.

Yozgat, Uğur ve Şişman, Fatma A. (2007), "Yeniden Yapılanma Süreci ve Bunun Çalışanların İs Tatmini ve Örgüte Bağlılıkları Üzerindeki Etkisi (Bir Kamu Kurumunda Araştırma)", 15. Ulusal Yönetim ve Organizasyon Kongresi Bildiriler Kitabı, Sakarya Üniversitesi IilBF Işletme Bölümü, Sakarya, ss. 745752. 